\title{
Peningkatan Hasil Belajar Siswa Pada Pembelajaran IPA Menggunakan Strategi Generatif Di Sekolah Dasar
}

\author{
Indriani Sevti Annisa \\ Sekolah Dasar Negeri 10 Sungai Sapih, Padang \\ * e-mail: indrianisevti@gmail.com
}

\begin{abstract}
This research was conducted due to the four grade student's low learning achievement at SDN 17 Manggis Ganting Kota Bukittinggi. The aim of this research was to describe the improvement of the student's learning achievement in Natural Science by using generatif strategy in the four grade of SDN 17 Manggis Ganting Kota Bukittinggi. This was a classroom action research which applied qualitative and quantitative approaches. The result of the research indicated that the student's learning achievement improved from 74 in the first cycle into 81,65 in the second cycle. Hence, the use of generatif strategy could improve the student's learning achievement in Natural Science in the four grade of SDN 17 Manggis Ganting Kota Bukittinggi.
\end{abstract}

Keywords: learning achievement; science; generatif strategy

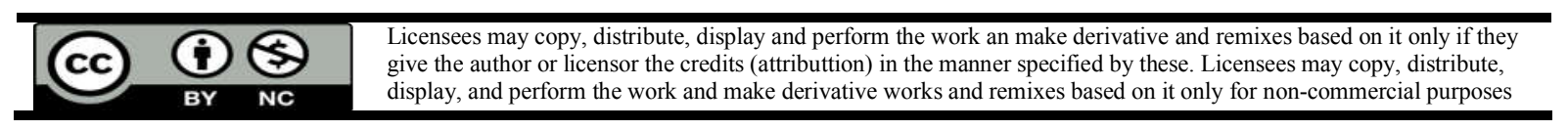

\section{PENDAHULUAN}

Ilmu Pengetahuan Alam merupakan mata pelajaran wajib di Sekolah Dasar. Mata pelajaran IPA diperlukan dalam kehidupan sehari-hari, khususnya dalam menghasilkan manusia yang berkualitas, yaitu manusia yang kreatif, berpikir kritis, mampu mengambil keputusan dan memecahkan masalahnya sendiri. Pendidikan Ilmu Pengetahuan Alam (IPA) sangat bermanfaat bagi kehidupan yaitu dapat menunjang ilmu pengetahuan dan teknologi, dimana proses pembelajaran IPA menuntut pengalaman langsung siswa agar dapat mengembangkan kemampuannya untuk menjelajahi dan memahami alam sekitar.

Hasil penelitian (Fatkur, 2013), menyimpulkan bahwa guru masih menyampai-kan materi secara langsung menggunakan metode ceramah. Padahal, pembelajaran sains dapat dilakukan dengan pengalaman langsung agar siswa dapat mengembangkan kemam-puannya dalam memahami lingkungan sekitar dan mampu mengambil keputusan serta memecahkan masalahnya sendiri.

Menurut (Putu Ari Susanti1, 2017) IPA berkaitan dengan cara mencari tahu tentang alam secara sistematis, sehingga IPA bukan hanya penguasaan kumpulan pengetahuan yang berupa fakta-fakta, konsep-konsep, atau prinsip-prinsip saja akan tetapi juga merupakan suatu proses penemuan. Pendidikan IPA diharapkan dapat menjadi wahana bagi peserta didik untuk mempelajari diri sendiri alam sekitar, serta prospek pengembangan lebih lanjut dalam penerapannya di dalam kehidupan sehari-hari.

Penelitian dilakukan berdasarkan pengamatan awal pada siswa SDN 17 Manggis Ganting Kota Bukittinggi. Berdasarkan pengamatan, pada pembelajaran IPA rencana pelaksanaan pembelajaran yang telah dibuat belum sesuai dengan kurikulum. Proses pembelajaran cenderung didominasi oleh pengajar (teacher centered). Kurang dikemas-nya pembelajaran IPA dengan pendekatan yang menarik, menantang, dan menyenangkan. Selain itu, guru juga kurang mengaitkan pem-belajaran dengan hal-hal nyata di sekitar siswa. 


\section{Indriani Sevti Annisa}

Jika hal-hal seperti ini terus dibiarkan begitu saja, siswa akan sulit menerima dan siswa lebih banyak mendengar dan menunggu sajian guru dari pada mencari dan menemukan sendiri pengetahuan serta keterampilan yang mereka butuhkan. Hasilnya, siswa memang memiliki banyak pengetahuan, akan tetapi siswa tidak dilatih untuk menemukan sendiri pengetahuan itu, dan tidak dilatih untuk mengembangkan ilmu pengetahuan itu secara mandiri. Siswa tidak mampu berfikir kritis, siswa bersikap tidak aktif seperti tidak terjadinya saling interaksi antar siswa maupun dengan guru. Tentu tujuan pembelajaran yang ditetapkan juga tidak akan tercapai secara optimal.

Proses pembelajaran di atas berdampak terhadap hasil belajar siswa pada pembelajaran IPA dimana hasil belajar siswa belum dapat tercapai secara maksimal sesuai dengan Kriteria Ketuntasan Minimal (KKM) yang ditetapkan. Untuk mengatasi permasala-han ini, maka perlu adanya upaya perbaikan proses pembelajaran yang dapat menumbuh-kan minat, motivasi, dan aktivitas belajar siswa sehingga dapat meningkatkan hasil belajar siswa. Salah satu alternatif tindakan yang dapat dilakukan adalah dengan menerapkan strategi generatif.

Wena (2009:183) mengemukakan bah-wa dengan pengetahuan awal (prior know-ledge) yang telah dimiliki sebelumnya dan menghubungkannya dengan konsep yang dipelajari, akhirnya siswa mampu mengkon-struksi pengetahuan baru.

\section{METODE}

Penelitian ini menggunakan jenis penelitian tindakan kelas (PTK) dengan menggunakan analisis data kualitatif dan kuantitatif dengan subjek penelitian siswa kelas IV SDN 17 Manggis Ganting Kota Bukittinggi, pada semester II Tahun Ajaran 2015/2016 dengan jumlah siswa 26 orang. (Data Primer SDN 17 Manggis Ganting Kota Bukittinggi, 2016). Penelitian ini menggunakan alur penelitian model Kemmis \& Mc Taggart (dalam Kunandar, 2008: 70-75): "Secara garis besar terdapat empat tahapan yang dilalui, yaitu (1) perencanaan, (2) pelak-sanaan, (3)pengamatan, dan (4) refleksi”.

Data penelitian berupa hasil pengamatan, dan tes dari pembelajaran IPA dengan strategi generatif pada siswa kelas IV SDN 17 Manggis Ganting Kota Bukittinggi. Data tersebut tentang hal-hal yang berkaitan dengan perencanaan pelaksanaan dan hasil pembelajaran yang berupa informasi pelaksanaan pembelajaran yang berhubungan dengan perilaku guru dan siswa yang meliputi interaksi pembelajaran antara guru-siswa, siswa-siswa, dan siswa-guru dalam pembelajaran IPA dan evaluasi pem-belajaran IPA baik yang berupa evaluasi proses maupun evaluasi hasil. Sumber data dari penelitian ini adalah proses IPA dengan strategi generatif di kelas IV SDN 17 Manggis Ganting Kota Bukittinggi yang meliputi perencanaan pembelajaran, pelaksanaan pembelajaran, ke-giatan evaluasi, perilaku guru dan siswa se-waktu proses pembelajaran. Data diperoleh dari subjek yang terteliti yakni guru (peneliti) dan siswa kelas IV SDN Manggis Ganting Kota Bukittinggi.

Sumber data penelitian adalah proses IPA dengan strategi generatif di kelas IV SDN 17 Manggis Ganting Kota Bukittinggi yang meliputi perencanaan pembelajaran, pelaksana-an pembelajaran, kegiatan evaluasi, perilaku guru dan siswa sewaktu proses pembelajaran. Data diperoleh dari subjek yang terteliti yakni guru (peneliti) dan siswa kelas IV SDN 17 Manggis Ganting Kota Bukittinggi.

Teknik pengumpulan data dilakukan secara observasi dan tes. Observasi dilakukan untuk mengamati latar kelas berlangsungnya pembelajaran IPA menggunakan strategi gene-ratif. Dengan berpedoman pada lembaran observasi, peneliti mengamati apa yang terjadi sela-ma proses pembelajaran. Sedangkan tes digunakan untuk memperkuat data observasi yang terjadi dalam kelas terutama pada butir penguasaan materi pembelajaran dari unsur siswa.

Instrumen penelitian dikumpulkan ber-dasarkan observasi terhadap RPP, pelaksanaan tindakan pembelajaran, dan tes hasil belajar. Data dikumpulkan selama empat hari dalam dua minggu yakni tanggal 12, 15, 26, dan 29 April 2016 dengan cara peneliti menjadi guru pengganti pelajaran IPA dengan menerapkan Strategi generatif di kelas IV SDN 17 Manggis Ganting Kota Bukittinggi.

\section{HASIL}




\section{Siklus I Pertemuan I \\ Perencanaan}

Materi pembelajaran dilaksanakan pada pertemuan I adalah perubahan lingkungan fisik yang disebabkan oleh erosi. Pembelajaran pertemuan I dilaksanakan dalam 1 kali pertemuan dengan alokasi waktu 2 × 35 menit. Penyusunan perencanaan tindakan dilakukan berdasarkan Kurikulum Tingkat Satuan Pendidikan (KTSP) dan dituangkan dalam seperangkat Rencana Pelaksanaan Pembelajaran (RPP). Standar Kompetensi (SK) yang peneliti ambil dari KTSP adalah Memahami perubahan lingkungan fisik dan pengaruhnya terhadap daratan, sedangkan Kompetensi Dasar (KD) yang peneliti ambil adalah Menjelaskan pengaruh perubahan lingkungan fisik terhadap daratan (erosi, abrasi, banjir dan longsor). Indikator pembelajaran ini adalah (1) Meng-identifikasi penyebab terjadinya erosi, (2) Menjelaskan dampak erosi terhadap lingku-ngan, (3) Mengidentifikasi usaha-usaha untuk mencegah terjadinya erosi, (4) Melakukan percobaan terjadinya erosi.

\section{Pelaksanaan}

Berdasarkan RPP yang disusun, pembelajaran pada penelitian melalui tiga langkah, yaitu kegiatan awal, kegiatan inti, dan kegiatan akhir dengan menggunakan Strategi generatif. Menurut Wena (2010:177) yaitu, pen-dahuluan/ eksplorasi, pemfokusan, tantangan/ pengenalan konsep, penerapan konsep.

\section{Pengamatan}

Pengamatan dilakukan setiap siklus, dimana hasil yang diperoleh yaitu berdasarkan hasil observasi terhadap RPP, yaitu dengan skor 23 dari skor maksimal 28, persentase 82,14\% dengan kategori sangat baik (SB). Berdasarkan hasil observasi yang dilakukan terhadap tindakan guru, dalam pembelajaran siklus I pertemuan I jumlah skor yang diperoleh 12 dari skor maksimal 16 dengan persentase $75 \%$ dengan kategori baik. Sedangkan siswa, skor yang diperoleh 13 dari skor maksimal 16 dengan persentase $81,25 \%$ dengan kategori sangat baik.

Hasil belajar siswa dilihat dari hasil evaluasi yang dilakukan. Berdasarkan hasil belajar diperoleh gambaran bahwa dari 26 siswa hanya 15 orang siswa mampu mencapai standar ketuntasan belajar dan 11 orang siswa belum mampu mencapai standar ketuntasan belajar. Persentase rata-rata kelas yaitu 71,28\%. Dari hasil belajar yang diperoleh dapat diuraikan: (1) Aspek kognitif, keberhasilan siswa dari aspek kognitif dilihat selama proses pembelajaran berlangsung selama siklus I pertemuan I dengan persentase rata-rata 63,65\% dengan kategori cukup (C); (2) Aspek afektif, Keberhasilan siswa dari aspek afektif pada pertemuan ini adalah 74,96\% dengan kategori baik (B); (3) Aspek psikomotor, Keberhasilan siswa dari aspek psikomotor pada pertemuan ini adalah $76,46 \%$ dengan kategori baik (B).

\section{Siklus I Pertemuan II}

\section{Perencanaan}

Materi pembelajaran dilaksanakan pada pertemuan II adalah perubahan lingkungan fisik yang disebabkan oleh abrasi. Pembelajaran pertemuan II dilaksanakan dalam 1 kali perte-muan dengan alokasi waktu 2 x 35 menit. Stan-dar Kompetensi (SK) yang peneliti ambil dari KTSP adalah Memahami perubahan lingkungan fisik dan pengaruhnya terhadap daratan, se-dangkan Kompetensi Dasar (KD) yang peneliti ambil adalah Menjelaskan pengaruh perubahan lingkungan fisik terhadap daratan (erosi, abrasi, banjir dan longsor). Indikator pembelajaran ini adalah (1) Mengidentifikasi penyebab terjadi-nya abrasi, (2) Menjelaskan dampak abrasi ter-hadap lingkungan, (3) Mengidentifikasi usaha-usaha untuk mencegah terjadinya abrasi, (4) Melakukan percobaan terjadinya abrasi.

\section{Pelaksanaan}

Berdasarkan RPP yang disusun, pembela-jaran pada penelitian melalui tiga langkah, yaitu kegiatan awal, kegiatan inti, dan kegiatan akhir dengan menggunakan Strategi generatif. Menurut Wena (2010:177) yaitu, pendahu-luan/eksplorasi, pemfokusan, tantangan/ pe-ngenalan konsep, penerapan konsep.

\section{Pengamatan}




\section{Indriani Sevti Annisa}

Pengamatan dilakukan setiap siklus, dimana hasil yang diperoleh yaitu berdasarkan hasil observasi terhadap RPP, yaitu dengan skor 24 dari skor maksimal 28, persentase $85,71 \%$ dengan kategori sangat baik (SB). Berdasarkan hasil observasi yang dilakukan terhadap tindakan guru, dalam pembelajaran siklus I pertemuan II jumlah skor yang diperoleh 13 dari skor maksimal 16 dengan persentase $81,25 \%$ dengan kategori sangat baik. Sedang-kan siswa, skor yang diperoleh 14 dari skor maksimal 16 dengan persentase $87,5 \%$ dengan kategori baik.

Hasil belajar siswa dilihat dari hasil evaluasi yang dilakukan. Berdasarkan hasil belajar diperoleh gambaran bahwa dari 26 siswa hanya 19 orang siswa mampu mencapai standar ketuntasan belajar dan 7 orang siswa belum mampu mencapai standar ketuntasan belajar. Persentase rata-rata kelas yaitu 76,64\%. Dari hasil belajar yang diperoleh dapat diuraikan: (1) Aspek kognitif, keberhasilan siswa dari aspek kognitif dilihat selama proses belajaran berlangsung selama siklus I pertemuan II dengan persentase rata-rata 78,38 \% du.ısun kategori baik (B); (2) Aspek afektif, Keberhasilan siswa dari aspek afektif pada pertemuan ini adalah 76,23\% dengan kategori baik (B); (3) Aspek psikomotor, Keberhasilan siswa dari aspek psikomotor pada pertemuan ini adalah 75,30\% dengan kategori baik (B).

\section{Siklus II Pertemuan I}

\section{Perencanaan}

Materi pembelajaran dilaksanakan pada pertemuan I adalah perubahan lingkungan fisik yang disebabkan oleh abrasi. Pembelajaran pertemuan I dilaksanakan dalam 1 kali pertemuan dengan alokasi waktu 2 x 35 menit. Standar Kompetensi (SK) yang peneliti ambil dari KTSP adalah Memahami perubahan lingkungan fisik dan pengaruhnya terhadap daratan, sedangkan Kompetensi Dasar (KD) yang peneliti ambil adalah Menjelaskan pengaruh perubahan lingkungan fisik terhadap daratan (erosi, abrasi, banjir dan longsor). Indikator pembelajaran ini adalah (1) Mengidentifikasi penyebab terjadinya banjir, (2) Menjelaskan dampak banjir terhadap lingkungan, (3) Mengidentifikasi usaha-usaha untuk mencegah terjadinya banjir, (4) Melakukan percobaan terjadinya banjir.

\section{Pelaksanaan}

Berdasarkan RPP yang disusun, pem-belajaran pada penelitian melalui tiga langkah, yaitu kegiatan awal, kegiatan inti, dan kegiatan akhir dengan menggunakan Strategi generatif. Menurut Wena (2010:177) yaitu, pendahuluan/ eksplorasi, pemfokusan, tantangan/ pengenalan konsep, penerapan konsep.

\section{Pengamatan}

Pengamatan dilakukan setiap siklus, dimana hasil yang diperoleh yaitu berdasarkan hasil observasi terhadap RPP, yaitu dengan skor 26 dari skor maksimal 28, persentase 92,85\% dengan kategori sangat baik (SB). Berdasarkan hasil observasi yang dilakukan terhadap tindakan guru, dalam pembelajaran siklus II pertemuan I jumlah skor yang diperoleh 14 dari skor maksimal 16 dengan persentase $87,5 \%$ dengan kategori sangat baik. Sedangkan siswa, skor yang diperoleh 14 dari skor maksimal 16 dengan persentase $87,5 \%$ dengan kategori sangat baik.

Hasil belajar siswa dilihat dari hasil evaluasi yang dilakukan. Berdasarkan hasil belajar diperoleh gambaran bahwa dari 26 siswa hanya 24 orang siswa mampu mencapai standar ketuntasan belajar dan 2 orang siswa belum mampu mencapai standar ketuntasan belajar. Persentase rata-rata kelas yaitu 79,78\%. Dari hasil belajar yang diperoleh dapat diuraikan: (1) Aspek kognitif, keberhasilan siswa dari aspek kognitif dilihat selama proses pembelajaran berlangsung selama siklus II pertemuan I dengan persentase rata-rata $78,84 \%$ dengan kategori baik (B); (2) Aspek afektif, Keberhasilan siswa dari aspek afektif pada pertemuan ini adalah 79,73\% dengan kategori baik (B); (3) Aspek psikomotor, Keberhasilan siswa dari aspek psikomotor pada pertemuan ini adalah $80,76 \%$ dengan kategori sangat baik (SB).

\section{Siklus II Pertemuan II \\ Perencanaan}

Materi pembelajaran dilaksanakan pada pertemuan II adalah perubahan lingkungan fisik yang disebabkan oleh abrasi. Pembelajaran pertemuan II dilaksanakan dalam 1 kali pertemuan dengan alokasi waktu 2 x 35 menit. Standar Kompetensi (SK) yang peneliti ambil dari KTSP 
adalah Memahami perubahan ling-kungan fisik dan pengaruhnya terhadap daratan, sedangkan Kompetensi Dasar (KD) yang peneliti ambil adalah Menjelaskan pengaruh perubahan lingkungan fisik terhadap daratan (erosi, abrasi, banjir dan longsor). Indikator pembelajaran ini adalah (1) Meng-identifikasi penyebab terjadinya longsor, (2) Menjelaskan dampak longsor terhadap lingkungan, (3) Mengidentifikasi usaha-usaha untuk mencegah terjadinya longsor, (4) Melakukan percobaan terjadinya longsor.

\section{Pelaksanaan}

Berdasarkan RPP yang disusun, pembelajaran pada penelitian melalui tiga langkah, yaitu kegiatan awal, kegiatan inti, dan kegiatan akhir dengan menggunakan Strategi generatif. Menurut Wena (2010:177) yaitu, pen-dahuluan/ eksplorasi, pemfokusan, tantangan/ pengenalan konsep, penerapan konsep.

\section{Pengamatan}

Pengamatan dilakukan setiap siklus, dimana hasil yang diperoleh yaitu berdasarkan hasil observasi terhadap RPP, yaitu dengan skor 26 dari skor maksimal 28, persentase $92,85 \%$ dengan kategori sangat baik (SB). Berdasarkan hasil observasi yang dilakukan terhadap tindakan guru, dalam pembelajaran siklus II pertemuan I jumlah skor yang diperoleh 15 dari skor maksimal 16 dengan persentase 93,75\% dengan kategori sangat baik. Sedangkan siswa, skor yang diperoleh 16 dari skor maksimal 16 dengan persentase $93,75 \%$ dengan kategori sangat baik.

Hasil belajar siswa dilihat dari hasil evaluasi yang dilakukan. Berdasarkan hasil belajar diperoleh gambaran bahwa dari 26 siswa, hanya 1 siswa yang belum mampu mencapai standar ketuntasan belajar. Persentase rata-rata kelas yaitu $82,84 \%$. Dari hasil belajar yang diperoleh dapat diuraikan: (1) Aspek kognitif, keberhasilan siswa dari aspek kognitif dilihat selama proses pembelajaran berlangsung selama siklus II pertemuan II dengan persentase rata-rata 80,19\% dengan kategori sangat baik (SB); (2) Aspek afektif, Keberhasilan siswa dari aspek afektif pada pertemuan ini adalah 83,76\% dengan kategori sangat baik (SB); (3) Aspek psikomotor, Keberhasilan siswa dari aspek psikomotor pada pertemuan ini adalah 84,03\% dengan kategori sangat baik (SB).

\section{PEMBAHASAN}

\section{Pembahasan Siklus I}

Langkah awal untuk memulai suatu penelitian adalah membuat perencanaan. Menu-rut Hakiim (2012:48) "Perencanaan pembelaja-ran meliputi silabus, dan rencana pelaksanaan pembelajaran yang memuat sekurang-kurang-nya tujuan pembelajaran, materi pembelajaran, metode pembelajaran, sumber belajar, dan evaluasi hasil belajar". Pada penelitian kali ini, peneliti menggunakan RPP sebagai perencana-an pembelajaran meng-gunakan strategi gene-ratif. RPP terdiri dari beberapa komponen yaitu: 1) Standar Kompetensi, 2) Kompetensi Dasar, 3) Indikator, 4) Tujuan Pembelajaran, 5) Materi pokok, 6) Kegiatan pembelajaran, 7) Media dan sumber, 8) Evaluasi. Standar Kompetensi dan Kompetensi Dasar diambil dari Kurikulum Tingkat Satuan Pendidikan (KTSP) IPA Kelas IV Sekolah Dasar.

Berdasarkan perencanaan yang disusun pelaksanaan pembelajaran dilaksanakan sesuai dengan apa yang telah direncanakan, yang mana pada siklus I pembelajaran disajikan dalam dua kali pertemuan (2x35menit). Pembelajaran pada siklus I dilaksanakan sesuai dengan langkahlangkah strategi generatif yaitu: 1) pendahu-luan/eksplorasi, 2) pemfokusan, 3) tantangan/ pengenalan konsep, dan 4) penerapan konsep. Berdasarkan catatan pada lembar observasi dan diskusi peneliti dengan pengamat penyebab dari masih rendahnya hasil belajar siswa pada siklus I secara garis besar adalah masih banyak siswa yang belum aktif dalam pembelajaran.

Pada saat guru praktisi melaksanakan penelitian, observer melakukan pengamatan dengan mengisi lembar pengamatan. Penilaian RPP untuk siklus I pertemuan I dalam taraf keberhasilan 83,14\% (sangat baik) dan siklus I pertemuan II 85,71\% (sangat baik), maka pada siklus I ini kemampuan merancang pembela-jaran dalam taraf keberhasilan 83,92\% (sangat baik). Kemudian untuk aktifitas guru siklus I pertemuan I dalam taraf keberhasilan $75 \%$ (baik) dan siklus I pertemuan II $81,25 \%$ (sangat baik), maka pada siklus I ini untuk aktivitas guru dalam taraf keberhasilan 78,12\% (baik). Untuk aktivitas siswa, siklus I per-temuan I dalam taraf keberhasilan 


\section{Indriani Sevti Annisa}

$81,25 \%$ (sangat baik) dan pada siklus I pertemuan II 87,5\% (sangat baik), maka pada siklus ini untuk aktifitas siswa berada dalam taraf keberhasilan 84,37\% (sangat baik).

Selain itu, dari hasil analisis penelitian siklus I pertemuan I nilai rata-rata siswa secara keseluruhan mencapai 71,28 dengan ketuntasan belajar 57,69\%. Sedangkan untuk siklus I pertemuan II sudah ada peningkatan. Ini terlihat dari rata-rata hasil belajar siswa yang mencapai 76,65 dengan ketuntasan belajar 73,07\%, maka untuk siklus I ini rata-rata hasil belajar siswa mencapai 74. Maka untuk siklus I ini siswa sudah mencapai KKM yang telah ditetapkan. Namun secara keseluruhan siklus I belum berhasil seutuhnya, karena persentase ketun-tasan belajar pada pertemuan II belum men-capai ketuntasan klasikal 75\% dimana ketun-tasan klasikal yang didapat pada pertemuan II yaitu $73,07 \%$. Ini menunjukkan bahwa nilai pada siklus I belum mencapai ketuntasan yang diharapkan. Untuk itu perlu diadakan tindakan dan dilanjutkan pada siklus II. Hal ini sejalan dengan pendapat Mulyasa (2009: 257) yang menyatakan "Proses pembentukan kompetensi dapat dikatakan berhasil apabila terjadi perubahan perilaku yang positif pada diri peserta didik seluruhnya atau setidak-tidaknya sebagian besar 75\% sesuai dengan kompetensi dasar".

Banyak hal yang ditemukan setelah refleksi siklus I dilakukan. Salah satunya berdasarkan hasil pengamatan Pembelajaran yang dilaksanakan guru belum sesuai dengan alokasi waktu yang telah ditetapkan. Kekurangan ini terjadi karena kurangnya ketelitian guru dalam memperkirakan waktu yang dibutuhkan. Muchlis (2007:46) menyatakan "Pembagian waktu setiap jam pertemuan didasarkan pada satuan tujuan pembelajaran atau sifat/tipe/jenis materi pembelaran". Oleh karena itu pada pertemuan selanjutnya guru harus menyesuaikan alokasi waktu yang telah ditetapkan agar pembelajaran berlangsung tepat waktu. Selain itu aktivitas guru, guru kurang memberikan motivasi kepada siswa untuk menyampaikan ide/gagasan yang ditemukannya. Guru juga kurang memberi bimbingan kepada siswa dalam mengerjakan tugas kelompok agar siswa lebih mengerti tentang apa yang akan dikerjakan siswa dalam kelompok. Oleh sebab itu sebaiknya guru harus lebih memotivasi dan membimbing siswa untuk menyampaikan ide/gagasan. Guru harus memberi bimbingan kepada siswa dalam mengerjakan tugas kelompok agar siswa lebih mengerti tentang apa yang akan dikerjakan siswa dalam kelompok. Hal ini karena siswa baru pertama kali melaksanakan pembelajaran seperti ini.

\section{Pembahasan Siklus II}

Rencana Pelaksanaan Pembelajaran (RPP) pada siklus II ini hampir sama dengan siklus I, namun dalam tahap penyelidikan, pengembangan materi, media yang digunakan dalam penyelidikan lebih dimaksimalkan. Pada saat guru praktisi melaksanakan penelitian, observer melakukan pengamatan dengan mengisi lembar pengamatan. Penilaian RPP untuk siklus II pertemuan I dalam taraf keberhasilan $92,85 \%$ (sangat baik) dan siklus II pertemuan II 92,85\% (sangat baik), maka pada siklus II ini kemampuan merancang pembelajaran dalam taraf keberhasilan 92,85\% (sangat baik). Kemudian untuk aktifitas guru siklus II pertemuan I dalam taraf keberhasilan 87,5\% (sangat baik) dan siklus II pertemuan II dalam taraf keberhasilan 93,75\% (sangat baik), maka pada siklus II ini aktifitas guru dalam taraf keberhasilan 90,62 \% (sangat baik).

Untuk aktivitas siswa siklus II pertemuan I dalam taraf keberhasilan 87,5\% (sangat baik) dan aktivitas siswa siklus II pertemuan II dalam taraf keberhasilan 93,75\% (sangat baik), maka pada siklus II ini aktifitas siswa dalam taraf keberhasilan 90,62\% (sangat baik). Dalam hal ini siswa kelihatan aktif dan dapat membangun pengetahuannya sendiri melalui kegiatan pembelajaran, temuan ini sejalan dengan pendapat Amaliah (2013:26) bahwa strategi generatif dapat membuat: "(1) siswa bersifat aktif dalam proses pembelajaran, (2) kemampuan pemahaman siswa yang tinggi dan rendah akan meningkat, (3) meningkatkan hasil belajar tanpa tambahan waktu, (4) siswa mampu menghasilkan kemampuan metakognisi”.

Selain itu, dari hasil analisis penelitian siklus II pertemuan II nilai rata-rata siswa secara keseluruhan mencapai 82,84 dengan ketuntasan belajar 96,05\%. Jika dibandingkan dengan siklus I pertemuan II dengan kompetensi dasar yang sama yaitu Menjelaskan pengaruh perubahan lingkungan fisik terhadap daratan (erosi, abrasi, banjir dan longsor), maka telah terjadi 
peningkatan. Untuk lebih jelasnya peningkatan hasil belajar siswa dari siklus I dan siklus II dapat terlihat dalam grafik dibawah ini.

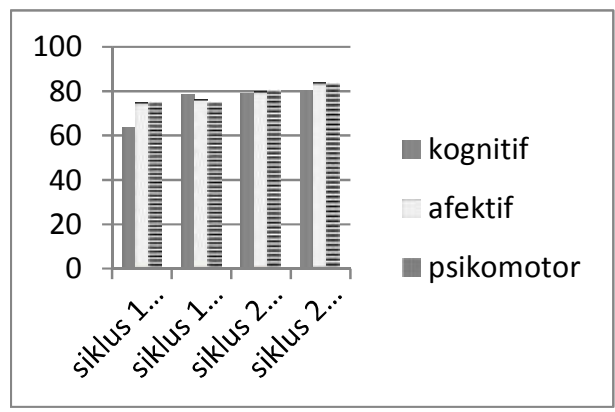

\section{Hasil Belajar Siswa}

Dari grafik diatas terlihat jelas bahwa setiap pertemuan, terjadi peningkatan rata-rata hasil belajar siswa, terlihat siklus I pertemuan I rata-rata hasil belajar siswa 71,28 dan siklus I pertemuan II hasil belajar siswa 76,65. Hal ini menunjukkan bahwa terjadi peningkatan 5,37. Pada siklus II pertemuan I rata-rata hasil belajar siswa 79,88 dan siklus I pertemuan II hasil belajar siswa 82,84. Disamping itu, juga terjadi perubahan dalam tahap kebiasaan, sikap, keterampilan, kesanggupan menghargai. Seperti yang dijelaskan Oemar (2008:2) "hasil belajar adalah tingkah laku yang timbul, misalnya dari yang tidak tahu menjadi tahu, timbul pertanyaan baru, perubahan dalam tahap kebiasaan, keterampilan, kesanggupan menghargai, perkembangan sikap sosial, emosional". Jadi dapat disimpulkan bahwa hasil belajar siswa sudah tuntas dan mencapai kriteria memuaskan. Oleh karena itu, penelitian ini berakhir di siklus II karena telah mencapai target yang telah ditetapkan. Kriteria keberhasilan setiap tindakan adalah 75\%. Sesuai dengan pendapat Kunandar (2009:149) bahwa standar ketuntasan pembelajaran adalah 75\%.

\section{SIMPULAN DAN SARAN}

Dari paparan data, hasil penelitian dan pembahasan simpulan yang dapat diambil dari penelitian ini adalah sebagai berikut: 1) Perencanaan pembelajaran yang dirancang dituangkan dalam bentuk RPP. RPP dirancang dengan tahapan strategi generatif dengan langkah secara umum pendahuluan/ eksplorasi, pemfokusan, tantangan/ pengenalan konsep, dan penerapan konsep. RPP siklus I diperoleh 83,92\% kemudian meningkat pada siklus II menjadi 92,85\% dengan kriteria keberhasilan sangat baik. 2) Pelaksanaan pembelajaran IPA dengan menerapkan strategi generatif terdiri dari kegiatan awal, kegiatan inti, dan kegiatan akhir. Pelaksanaan pembelajaran IPA dengan menerapkan strategi generatif dilaksanakan dengan langkah-langkah: pendahuluan/eksplorasi, pemfokusan, tantang-an/ pengenalan konsep, dan penerapan konsep. Pelaksanaan pembela-jaran dengan strategi generatif melibatkan penilain dari aspek guru dan aspek siswa. Rekapitulasi hasil penilaian aspek guru siklus I dan siklus II yaitu 78,12\% meningkat menjadi $90,62 \%$ dan rekapitulasi hasil penilaian proses pada siklus I juga sudah mengalami peningkatan pada siklus II dengan perolehan nilai Sangat baik. Sedangkan penilaian aspek siswa, rekapitulasi hasil penilaian aspek siswa siklus II lebih tinggi jika dibandingkan dengan rekapitulasi hasil penilaian aspek siswa siklus I yaitu 84,37\% meningkat menjadi 90,62\%. 3) Penerapan strategi generatif dalam pembelajaran IPA di kelas IV SDN 17 Manggis Ganting Kota Bukittinggi dapat meningkatkan hasil belajar siswa. Hal ini dapat dilihat dari rekapitulasi hasil belajar siswa siklus II lebih tinggi jika dibandingkan dengan rekapitulasi hasil belajar siswa siklus I yaitu 74\% (B) meningkat menjadi $81,65 \%$ (SB).

Berdasarkan hasil penelitian dan pembahasan serta simpulan yang diperoleh, dapat dikemukakan saran yang sekiranya dapat memberikan masukan untuk peningkatan hasil belajar IPA sebagai berikut: 1) Rencana Pelaksanaan Pembelajaran IPA hendaknya dirancang sesuai dengan langkah-langkah strategi generatif sehingga proses pembelajaran menjadi menyenangkan bagi siswa. 2) Pelaksanakan pembelajaran IPA hendaknya menggunakan langkah-langkah strategi generatif dan memanfaatkan waktu sebaik mungkin, sehingga hasil belajar siswa menjadi meningkat. 3) Strategi generatif ini dapat dipertimbangkan oleh guru untuk menjadi salah satu alternatif strategi pembelajaran IPA untuk meningkatkan hasil belajar siswa, karena pembelajaran 


\section{Indriani Sevti Annisa}

dengan strategi ini membuat siswa menjadi aktif, kemampuan pemahaman siswa yang tinggi dan rendah akan meningkat, dan siswa mampu mengaitkan pengetahuan yang telah dimiliki sebelumnya dengan materi yang diterimanya sehingga siswa dapat membangun pengetahuan baru secara mandiri dan mengaplikasikannya dalam kehidupan.

\section{DAFTAR RUJUKAN}

Arikunto, Suharsimi. 2009. Penelitian Tindakan Kelas. Jakarta: BumiAksara

Fatkur, T. R. (2013). Peningkatan Pembelajaran Pelestarian Alam Melalui Metode Field Trip Siswa Sekolah Dasar. Journal of Elementary Education, 2(4), 29-35. Retrieved from http://journal.unnes.ac.id/sju/index.php/jee\%0APENINGKATAN

Kunandar. 2008. Langkah-langkah PTK sebagai Pengembangan Profesi Guru. Jakarta: Rajawali Pers

Hakiim, Lukmanul. 2012. Perencanaan Pembelajaran. Bandung: Wacana Prima

Muchlis, Masnur. 2007. KTSP (Kurikulum Tingkat Satuan Pendidikan) Dasar Pemahaman dan Pengembangan. Jakarta : Bumi Aksara

Mulyasa. 2010. Implementasi KTSP Kemandirian Guru dan Kepala Sekolah. Jakarta: Bumi Aksara

Putu Ari Susanti1, N. N. K. (2017). Penerapan Model Picture and Picture Berbasis Pendekatan Saintifik Untuk Meningkatkan Hasil. Jurnal Ilmiah Sekolah Dasar, 1(2), 99-106.

Wena, Made. 2009. Strategi Pembelajaran Inovatif Kontemporer. Jakarta: Bumi Aksara 